\title{
The Role of Education in Sustainable Dietary Patterns in Slovenia
}

\author{
Andrej Kirbiš ${ }^{1, *}$, Monika Lamot ${ }^{1}$ and Marija Javornik ${ }^{2}$ \\ 1 Department of Sociology, Faculty of Arts, University of Maribor, Koroška Cesta 160, 2000 Maribor, Slovenia; \\ monika.lamot@student.um.si \\ 2 Department of Pedagogy, Faculty of Arts, University of Maribor, Koroška Cesta 160, 2000 Maribor, Slovenia; \\ marija.javornik@um.si \\ * Correspondence: andrej.kirbis@um.si
}

Citation: Kirbiš, A.; Lamot, M.; Javornik, M. The Role of Education in Sustainable Dietary Patterns in Slovenia. Sustainability 2021, 13, 13036. https://doi.org/10.3390/ su132313036

Academic Editor:

Alessandra Durazzo

Received: 23 September 2021

Accepted: 19 November 2021

Published: 25 November 2021

Publisher's Note: MDPI stays neutral with regard to jurisdictional claims in published maps and institutional affiliations.

Copyright: (c) 2021 by the authors. Licensee MDPI, Basel, Switzerland. This article is an open access article distributed under the terms and conditions of the Creative Commons Attribution (CC BY) license (https:/ / creativecommons.org/licenses/by/ $4.0 /)$.

\begin{abstract}
The most sustainable dietary patterns involve the consumption of plant-based (vegan) foods, excluding or reducing animal products, including meat, fish, and dairy, yet there is a lack of research on determinants of sustainable dietary patterns in central European countries. The present article aimed to examine the prevalence of sustainable dietary practices and attitudes among the Slovenian public and to investigate the role of education in fostering sustainable dietary patterns. We analyzed a representative national sample of Slovenians, with data gathered in 2019 (ISSP/Slovenian Public Opinion; N = 1079; 51.2\% females). The results indicate that most Slovenians do not have sustainable dietary practices or attitudes with regard to health, the environment, animals, and dietary minorities. One in four Slovenians consume meat at least once per day and one in two consume meat three to six times per week. In addition, $78.2 \%$ of Slovenians consume milk at least three times per week; more than half consume milk daily or more often. Fish consumption is the least frequent among the three food groups. At least two-thirds of Slovenians also hold attitudes that are low in sustainability. Results also show that, after controlling for confounding variables, higher educational level emerged as an independent predictor of lower meat consumption, but not of lower fish or milk consumption. Furthermore, those in the lowest educational group are significantly less likely to hold sustainable attitudes than those in the higher educational group. Finally, current student status only decreases meat consumption. Since our results show an educational gradient in meat consumption and attitudes, public health and environmental campaigns should focus on the less-educated groups, encouraging them to reduce meat intake and fostering more sustainable attitudes.
\end{abstract}

Keywords: dietary patterns; education; sustainability; attitudes; meat; animals

\section{Introduction}

Ample evidence suggests that the most sustainable dietary patterns involve the consumption of plant-based (vegan) foods, excluding or reducing animal products, including meat, eggs, fish, and dairy [1-3]. Plant-based and meat-avoidance diets rank highest on sustainability in several ways: they have the smallest environmental footprint; they have a beneficial impact on human health and wellbeing; and they take into account animal welfare (i.e., the ethics of excluding, as far as possible and practicable, all forms of animal exploitation and cruelty to animals) $[1,4,5]$.

The present article examines the prevalence of sustainable dietary practices and attitudes among the Slovenian public, and the role education plays in fostering sustainable dietary patterns. Sustainability is defined as "the continued protection of human health and the environment while fostering economic prosperity and societal wellbeing" [6] (p. 5). After a brief overview of the literature on sustainable dietary practices and the role of education in promoting sustainable patterns in the first part of the article, we then examine empirical data from a representative sample of Slovenians with regard to the distribution of sustainable dietary practices and attitudes. In addition, we test whether education 
(measured as educational level and current educational status, i.e., currently (not) being in the educational process) are associated with sustainable dietary practices and attitudes. We perform bivariate and multivariate analyses controlling for demographic and economic confounders. In the last section of the article, we discuss the implications of our findings, particularly for the educational process.

\subsection{Sustainable Diets: Human Health, Environment, and Ethics}

Sustainable development refers to "a paradigm shift from a development based on inequity and overexploitation of natural resources and environmental services, to one that requires new forms of responsibility, solidarity and accountability" [7] (p. 559). Food systems and dietary patterns are among the critical elements of sustainability. Sustainable diets have been defined by the Food and Agriculture Organization of the United Nations (FAO) as "diets with low environmental impacts which contribute to food and nutrition security and to healthy life for present and future generations. Sustainable diets are protective and respectful of biodiversity and ecosystems, culturally acceptable, accessible, economically fair and affordable; nutritionally adequate, safe and healthy; while optimizing natural and human resources" [8] (p. 89).

The transition towards more sustainable diets is a global challenge since behavioral change aimed at more sustainable dietary patterns is underpinned by various factors and motives. Environmental, health, and ethical concerns are the main motives of dietary behavior change for those moving towards a more sustainable, plant-based diet consumption and reducing or fully eliminating meat intake (i.e., vegetarians and vegans) [9-11]. Numerous studies show plant-based, vegan, and vegetarian diets and heavily meat-reduced diets may be the optimal diet for the environment [1,12]. Animal products, on the other hand, are linked to poor health outcomes. Studies show processed meat has the most detrimental impact on health, followed by red meat $[13,14]$. The ethical dimension of sustainable diets also needs to be considered. As non-human animals are a part of nature, ethical concerns have been raised by scholars regarding the human consumption of animals and animal products [15]. Decreasing consumer demand for less sustainable food, especially meat, could minimize harm, suffering, and death to sentient animals in the livestock industry [16].

Diet-related aspects of sustainability are largely interlinked. Solutions to addressing the question of human and environmental health through dietary change therefore strongly overlap. Intensive meat production, for example, is on an "unstoppable trajectory comprising the single greatest contributor to climate change. [ ... ] Humanity's dominant diets are not good for us, and they are not good for the planet" [17] (p. 387), neither are they good for human treatment of animals [18]. As argued by Kjærgård and colleagues, "many health and sustainability problems emerge as a consequence of society's appropriation of natural resources and the overexploitation of environmental services such as carbon sequestration and biodiversity [ ... ] many public health and environmental problems are caused by the increased intensification of agriculture and food production" [7] (p. 558).

\subsection{The Impact of Education on Sustainable Dietary Patterns and Attitudes}

Since dietary patterns play such a strong role in all three dimensions of sustainability, there is a clear need for understanding the various factors that impact dietary patterns. For example, several demographic, economic, social, and environmental determinants of sustainable dietary practices and attitudes have previously been detected [19-22]. In addition, studies show that education is among the most important determinants of dietary behavior [23,24] and lifestyles [25]. The more educated groups consume meat less frequently in the U.S. [20], Great Britain [26,27], Denmark [28], Germany [29], and Slovenia [19]. The more educated are also more likely to currently be meat avoiders [30] and are more willing to reduce meat intake in the future [31]. Vegetarians and vegans are also more likely to be better educated [32,33], including in Slovenia [9].

Several mechanisms may explain the link between healthier and more sustainable dietary choices and education. Education may be conducive to more sustainable diets, e.g., 
meat reduction, because it fosters scientism and the ability to seek and use new sources of information [34], including food-related information. For example, people with high levels of education have better dietary knowledge and diet-related information acquisition behaviors, e.g., reading food labels [35-38]. In Denmark, for example, members of the highest educated groups are almost 2.6 times more likely to follow dietary recommendations regarding red meat intake and two times more likely to follow fruit and vegetable intake recommendations than those with primary education [28]. Less educated individuals, for example, were found to be more likely to worry (needlessly) that plant-based diets would not be sufficiently filling, would not suffice in protein, and would present a risk to their health [39], despite the overwhelming scientific evidence on the beneficial health effects of vegan and plant-based diets [5,40-44]. Better-educated individuals are more likely to correctly believe that increased fiber intake is a benefit of eating a plant-based diet [39]. Only a few studies show that education plays no role in dietary patterns. For example, in a study by Bryant [31], vegan diet was not perceived as healthier or more environmentally friendly by better educated individuals.

When discussing sustainable dietary patterns, sustainable attitudes should also be taken into account. For example, the link between education and dietary behavior could be explained by one's attitudes and values. For this reason, determining how education impacts attitudes toward foods is also important, since attitudes impact dietary behavior patterns. For example, positive attitudes toward meat (e.g., in the form of meat attachment) are linked to more frequent consumption of meat, decreased willingness to consider changing one's eating habits, and increased endorsement of values of human dominance over animals [45].

Intolerant attitudes toward food minorities (e.g., vegans) could also impact the prevalence of sustainable dietary practices. In its detailed statement of values for sustainable development, the General Assembly of the United Nations adopted a set of fundamental values for sustainable development, including tolerance, which comprises respect for other people, despite their diverse beliefs, culture, and language [46]. Education was found to have a positive impact on tolerant (i.e., sustainable) attitudes toward various minorities $[47,48]$, and the link between education and attitudes toward vegans and vegan diets is similarly positive. For example, a vegan diet is seen as more ethical by better educated individuals [31], who also express attitudes that are more positive toward vegans than lower-educated individuals [30].

\subsection{Study Aim}

Despite previous studies in developed countries, it remains unclear whether educational level and current educational status are linked to sustainable dietary behavior and attitudes in central and eastern European countries, since what we know about the educational gradient in sustainable dietary patterns is largely based on studies of people living in Western cultural environments. In addition, a recent systematic review of health-related values and preferences regarding meat consumption in high-income countries reported that studies failed to consistently report, among other variables, participants' educational level, thus precluding any analysis of its effect on dietary values and preferences [49]. The few existing studies in post-communist countries found education to be a significant and consistent predictor of sustainable attitudes (e.g., environmental concerns), but those studies did not focus on dietary behavior and attitudes [50].

The main aim of our study was therefore to examine the prevalence of sustainable dietary patterns (behaviors and attitudes) among the Slovenian public using a representative national sample. In addition, we examined whether one's educational level and current educational status (being in the educational process) impact one's sustainable dietary behavior patterns (low or no meat, fish, and milk consumption) and sustainable attitudes (dietary knowledge regarding food health and environmental impact, ethical views towards animals and tolerance toward vegans), when controlling for confounding factors. Taking confounders into account is crucial, since meat consumption, for example, 
was previously found linked to factors such as gender, age, partner status, household size, and size of residential settlement $[20,21,29,32,33]$.

\section{Materials and Methods}

\subsection{Data and Sample Description}

We carried out a secondary analysis of a representative national sample of Slovenians (Slovenian Public Opinion-SPO) [51]. The data were gathered in 2019 ( $\mathrm{N}=1079$; $51.2 \%$ females). SPO 2019 was part of the International Social Survey Program [52]. SPO thus followed ISSP ethical guidelines [53]. ISSP source questionnaires are developed and pretested by international teams and discussed and approved by the ISSP General Assembly, a major deliberative, decision-making, and representative organ of the ISSP [53]. ISSP and SPO survey data are anonymized for secondary analysis, so that individual survey participants cannot be identified; moreover, informed consent is acquired for survey participants. SPO surveys routinely use the Central Register of Population (a list of names and addresses constantly updated by public administration) as a sampling frame. The sample was a two-stage, stratified, random sample from the Central Register of Population, where each population unit had an equal probability of selection. The SPO sample consisted of individuals over 18 living in private households, regardless of their nationality, citizenship, language, or legal status in Slovenia. Face-to-face interviews were carried out in the form of computer-assisted personal interviewing (CAPI) and computer-assisted mobile interviewing (CAMI) [54]. All analyses were computed with IBM SPSS Statistics (version 28, IBM Corp, New York, NY, USA).

\subsection{Measurement}

We examined several constructs relating to sustainable dietary patterns. We recoded original items for the present study, whereby higher values indicate more sustainable behavior/attitudes.

\subsubsection{Outcome Variables}

Sustainable dietary behavior patterns were measured with the frequency of consumption of three food groups: meat and meat products; fish; and milk or dairy products (1-never; 2-rarely (one to three times per year); 3 -occasionally (less than once per week); 4 -frequent (one to two times per week); 5 - several times a week (three to six times per week); 6-daily (at least once per day)).

Sustainable attitudes were measured with several items. Dietary health knowledge was assessed with a question: "People who do not eat meat and meat products are healthier" (1-fully disagree; 5-fully agree). Dietary environmental knowledge was assessed with a question: "In order to protect the environment effectively, it is essential to avoid food of animal origin" (1-fully disagree; 5-fully agree). In addition, ethically sustainable views of animal food consumption were tapped with the following item: "Eating meat seems ethically questionable to me" (1-fully disagree; 5 -fully agree). Finally, attitudes toward vegans were measured with the following two items: "People who eat neither meat, fish, nor milk and dairy products, and refuse to use products of animal origin are far too radical," and "Parents who do not allow minors to eat meat, fish, or dairy foods should be tracked by social services and their children should be protected" (1-fully agree; 5-fully disagree). We combined both items into an additive index, which proved sufficiently reliable (rho $=0.36 ; p<0.001)$, with higher values indicating greater tolerance toward vegans (i.e., more sustainable attitudes).

Since all attitudinal variables were significantly and positively associated and formed a one-factor solution in principal component analysis, a combined sustainable attitudes scale (Cronbach's Alpha $=0.68)$ was used in the multivariate analyses. 


\subsubsection{Educational Predictor Variables}

Two educational predictors were used. Current educational status was a dichotomized answer concerning the respondent's main activity $(0=$ not in education; $1=$ in education). Educational level was tapped with a question: "Indicate the last school from which you graduated, full-time or part-time". The original twelve categories were recoded into three categories: 1 = primary school or less; $2=$ some secondary education; $3=$ some higher education.

\subsubsection{Control Variables}

We included several control variables in our multivariate models: gender $(1=$ male; 2 = female); age (in years); size of residential settlement ( $1=$ less than 2000 inhabitants; $2=2000-10,000$ inhabitants; $3=$ more than 10,000 inhabitants $)$; household size $(1=$ a single person, 2 = two people; 3 = three or more people in a household). In addition, respondent's economic status was tapped with two questions: "If you compare yourself to the people around you, do you think that you are financially doing better, the same, or worse than them?" (0-much worse; 10 -much better) and "How do you assess the material conditions in which you and your family live? To what extent are you satisfied or dissatisfied with the material situation in your family?" (0—much worse than others; 10 -much better than others). Both economic items were combined in an additive index (rho $=0.47 ; p<0.001$ ).

\subsection{Plan of Analysis}

We first performed descriptive analysis on our outcome variables-sustainable dietary behavior and attitudes. We then calculated bivariate associations between both educational predictors and outcomes variables. Third, we performed four ordinal regression analyses on behavioral and attitudinal outcome variables, controlling for confounding factors (Figure 1).

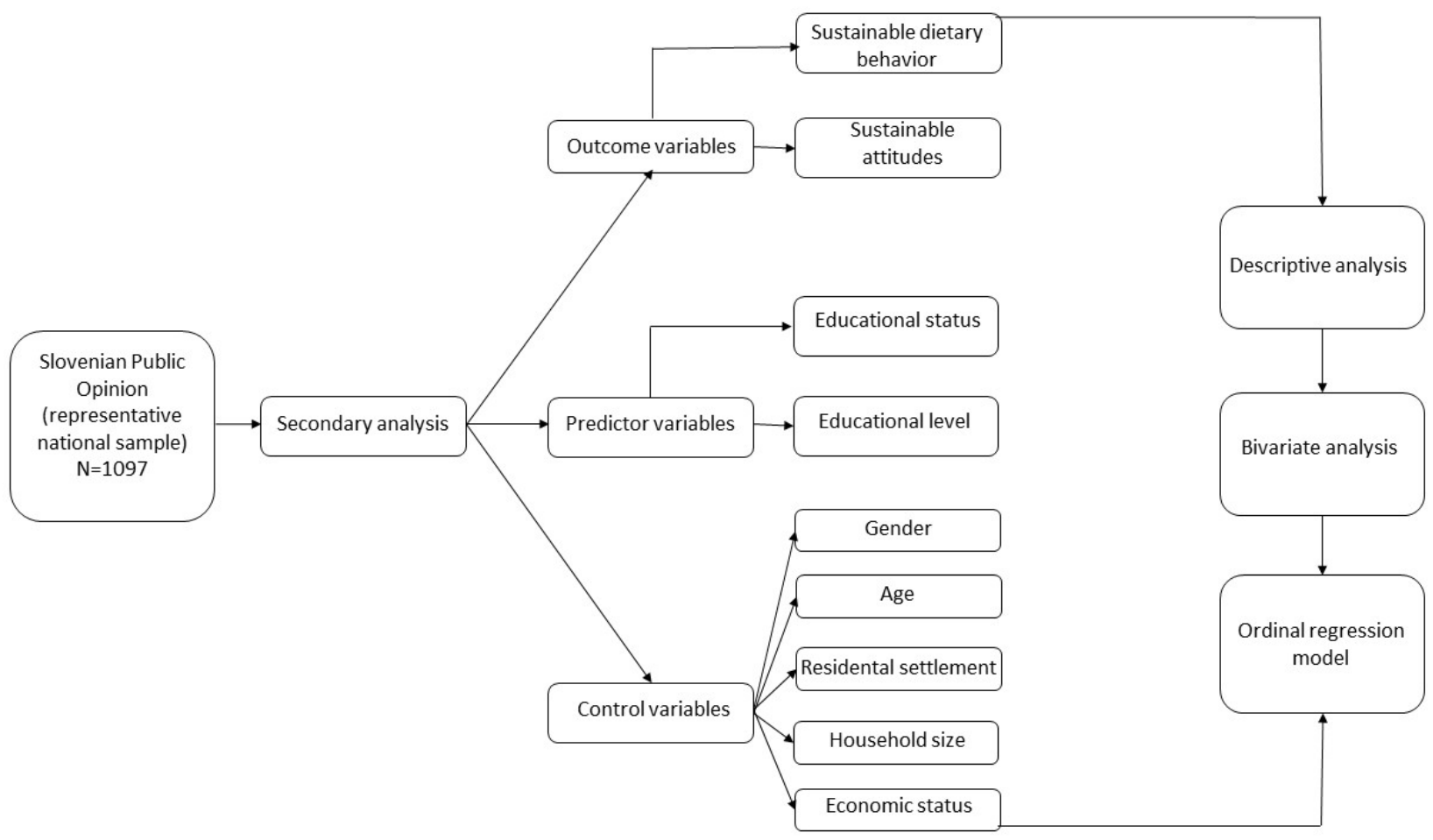

Figure 1. Methodology of the study. 


\section{Results}

\subsection{Descriptive Analysis}

Table 1 shows the frequency of sustainability of dietary behavior patterns among Slovenians. Almost a quarter of Slovenians consume meat at least once per day, and almost $55 \%$ consume it three to six times per week. Only $6.4 \%$ of Slovenians reported highly sustainable meat consumption patterns, consuming meat occasionally or even more rarely. Overall, meat consumption is very frequent, with almost four out of five Slovenians consuming meat at least three times a week.

Table 1. Descriptive analysis of sustainable dietary behavior patterns (meat, fish, and milk consumption) (\%).

\begin{tabular}{cccc}
\hline & Meat & Fish & Milk \\
\hline Daily (at least once per day) & 24.0 & 1.2 & 50.1 \\
Several times a week (three to six times per week) & 54.9 & 9.2 & 28.1 \\
Frequent (once to twice per week) & 14.7 & 34.2 & 10.8 \\
Occasionally (less than once per week) & 4.4 & 40.7 & 5.9 \\
Rarely (one to three times per year) & 0.6 & 10.8 & 2.1 \\
Never & 1.4 & 3.9 & 3.0 \\
Mean (1-6) & 2.07 & 3.62 & 1.91 \\
\hline
\end{tabular}

Source: Slovenian Public Opinion 2019 [51].

Fish consumption, on the other hand, is much less frequent. In the sample, 55.4\% of respondents reported consuming fish less than once per week or even more rarely, indicating a more sustainable dietary pattern than meat consumption. Milk consumption, on the other hand, has a national consumption pattern similar to that for meat consumption. The survey showed $78.2 \%$ of Slovenians consume milk at least three times per week; more than half consume it daily or more often. Only $11 \%$ consume milk less than once per week.

Overall, our analyses indicate the majority of Slovenians have diets that are low in sustainability as related to animal-sourced food consumption.

Turning to attitudinal dimensions, Table 2 shows the prevalence of sustainable attitudes among Slovenians. Results indicate a picture similar to that for behavior dietary patterns. Around two-thirds of Slovenians hold attitudes that are low in sustainability. A similar proportion of Slovenians (64.6\%) have poor dietary health knowledge, almost $74 \%$ have poor dietary environmental knowledge, and almost $80 \%$ hold ethically unsustainable views of animals. Similarly, lack of tolerance for vegans is also prevalent; $68.7 \%$ are intolerant toward vegans and $63.9 \%$ are intolerant toward vegan parents.

Table 2. Descriptive analysis of sustainable dietary attitudes (\%).

\begin{tabular}{cccccc}
\hline & $\begin{array}{c}\text { Dietary Health } \\
\text { Knowledge }\end{array}$ & $\begin{array}{c}\text { Dietary } \\
\text { Environmental } \\
\text { Knowledge }\end{array}$ & $\begin{array}{c}\text { Ethically } \\
\text { Sustainable } \\
\text { Views of } \\
\text { Animals }\end{array}$ & $\begin{array}{c}\text { Tolerance of } \\
\text { Vegans }\end{array}$ & $\begin{array}{c}\text { Tolerance of } \\
\text { Vegan Parents }\end{array}$ \\
\hline Fully disagree & 20.0 & 23.1 & 28.9 & 27.7 & 24.2 \\
Disagree & 44.6 & 50.6 & 51.0 & 41.0 & 39.7 \\
Neither & 25.5 & 16.1 & 13.7 & 17.5 & 18.1 \\
Agree & 8.2 & 8.5 & 5.0 & 10.3 & 13.8 \\
Strongly agree & 1.7 & 1.6 & 1.4 & 3.4 & 4.2 \\
Mean (1-5) & 2.27 & 2.15 & 1.99 & 2.21 & 2.34 \\
\hline
\end{tabular}




\subsection{Bivariate Associations}

Results in Table 3 show bivariate associations between our variables of interest. Line 1 in Table 3 shows whether Slovenians with higher educational levels have more sustainable dietary patterns. We see that those with higher education consume meat less frequently but fish more frequently, while milk consumption does not differ significantly between educational groups. Line 2 indicates that currently being in the educational process is not linked to any of the dietary patterns. Line 3 indicates that educational level is linked to four out of five unsustainable attitudes, with better-educated individuals expressing more sustainable attitudes than those with lower educational levels. The exception is dietary health knowledge, which is not significantly linked to educational levels. Educational status is linked only to tolerance for vegans; those currently in education express more tolerance toward vegans, while the other four attitudes are not significantly impacted by educational status.

Table 3. Bivariate correlations between educational level, educational status, and sustainable dietary behavior patterns and attitudes.

\begin{tabular}{|c|c|c|c|c|c|}
\hline & Meat (Low or No) & Fish (Low or No) & Milk (Low or No) & & \\
\hline \multirow{3}{*}{$\begin{array}{l}\text { 1. Educational level } \\
\text { 2. Educational status } \\
\text { (in education) }\end{array}$} & $0.09^{* *}$ & $-0.06^{*}$ & -0.03 & & \\
\hline & -0.02 & 0.02 & 0.06 & & \\
\hline & $\begin{array}{l}\text { Dietary health } \\
\text { knowledge }\end{array}$ & $\begin{array}{c}\text { Dietary } \\
\text { environmental } \\
\text { knowledge }\end{array}$ & $\begin{array}{c}\text { Ethically } \\
\text { sustainable views } \\
\text { of animals }\end{array}$ & $\begin{array}{c}\text { Tolerance of } \\
\text { vegans }\end{array}$ & $\begin{array}{c}\text { Tolerance of } \\
\text { vegan parents }\end{array}$ \\
\hline 3. Educational level & 0.05 & $0.13^{* * *}$ & 0.13 ** & $0.10^{* * *}$ & $0.13^{* * *}$ \\
\hline 4. Educational status & 0.02 & 0.01 & -0.01 & $0.11^{* * *}$ & 0.06 \\
\hline
\end{tabular}

Source: Slovenian Public Opinion 2019 [51]. Notes: * $p<0.05 ;{ }^{* *} p<0.01 ;{ }^{* * *} p<0.001$.

\subsection{Multivariate Analysis}

Table 4 shows ordinal regression analyses of the impact of educational level and educational status on four outcome variables of sustainability: (low or no) meat, fish, and milk consumption and the sustainable attitudes scale, controlling for demographic and economic variables. Results indicate that higher educational level is an independent predictor of lower meat consumption; compared to those with at least some higher education, meat consumption is more frequent among those with secondary education and even more frequent among those with primary school or less. Specifically, compared to the tertiary educational group, those with secondary education have 0.68 odds $(\operatorname{Exp}(-0.39))$ of being in a higher category of more sustainable (less frequent) meat intake, and those with primary school have just over half the odds $(0.55)(\operatorname{Exp}(-0.60))$, adjusted for control variables. The educational level had no significant impact on fish or milk consumption when controlling for confounding factors. Finally, those in the higher educational group expressed sustainable attitudes significantly more frequently $(1.97$ the odds $(\operatorname{Exp}(0.68)))$ than those in lowest educational group, adjusted for control variables.

Educational status also had an impact, but on only one of the four examined sustainability outcomes. Those currently in the educational process reported lower meat consumption (controlling for other factors) with twice the odds of reporting less frequent meat intake. In contrast, educational status had no independent impact on fish or milk consumption nor on sustainable attitudes. 
Table 4. Ordinal regression model (parameter estimates) predicting sustainable dietary patterns among the Slovenian public.

\begin{tabular}{|c|c|c|c|c|c|}
\hline & & Meat (Low or No) & Fish (Low or No) & Milk (Low or No) & $\begin{array}{c}\text { Sustainable } \\
\text { Attitudes }\end{array}$ \\
\hline & & \multicolumn{4}{|c|}{ Parameter Estimates } \\
\hline \multirow[t]{2}{*}{ Educational level ${ }^{1}$} & $\begin{array}{l}\text { Primary school or } \\
\text { less }\end{array}$ & $-0.60 * *$ & -0.07 & 0.19 & $-0.51 *$ \\
\hline & $\begin{array}{l}\text { Some secondary } \\
\text { school }\end{array}$ & $-0.39 * *$ & -0.23 & 0.06 & -0.10 \\
\hline Educational status ${ }^{2}$ & Not in education & $-0.68 *$ & -0.26 & -0.26 & -0.02 \\
\hline $\mathrm{R}^{2}$ (Nagelkerke) & & 0.105 & 0.035 & 0.025 & 0.047 \\
\hline
\end{tabular}

Source: Slovenian Public Opinion 2019 [51]. Notes: ${ }^{*} p<0.05 ;{ }^{* *} p<0.01 ; \mathrm{R}^{2}=0.23$ (Nagelkerke). Reference categories: ${ }^{1}$ Some tertiary education; ${ }^{2}$ In education. Adjusted for gender, age, size of the residential settlement, household size, self-assessed economic status, and income.

\section{Discussion}

In the present study, we examined the prevalence of sustainable dietary behavior patterns and attitudes among Slovenians. We also examined whether educational level and current educational status were linked to sustainable dietary behavior patterns (low or no meat, fish, and milk consumption) and sustainable attitudes, net of confounding factors.

We found that most Slovenians do not have sustainable dietary practices, nor do they hold sustainable attitudes with regard to health, the environment, animals, and dietary minorities. While fish consumption is the least frequent among the three food groups, one in four Slovenians consume meat at least once per day, and one in two consume meat three to six times per week. In addition, $78.2 \%$ of Slovenians consume milk at least three times per week; more than half consume milk daily or more often. Our results are in line with some earlier studies of dietary habits in Slovenia. Compared to a study in 2008 [19], our results tentatively suggest that meat consumption may have increased between 2008 and 2019. Nonetheless, longitudinal studies are needed to examine changes in dietary patterns in Slovenia and other post-communist countries, along with the determinants that may have influenced these.

We also found that education does not promote sustainable dietary habits across the board when controlling for confounders. We found education linked only to meat consumption and sustainable attitudes but not to the consumption of milk and fish. Our results agree with previous studies indicating that those with more education consume meat less frequently $[20,27,29]$. In contrast, some studies show that meat intake does not increase in a stepwise fashion as individuals are more educationally disadvantaged, although the least educated and most educated groups have expected differences in meat intake [55]. In some studies, specific types of meat were found not to be significantly linked with educational level $[28,56]$. Previous Slovenian studies similarly found that meat consumption had an educational gradient, with some types of meat being consumed twice as frequently among those with primary school education than among those with higher education [19].

Our results thus show that education is linked to more sustainable dietary behavior patterns when it comes to meat consumption. Several mechanisms may be at play. For example, education may increase health awareness [57], which can then translate into proactive health behavior. Education is also linked to scientism, which may increase foodrelated knowledge, leading to more sustainable dietary behavior [58]. Another possible explanation is that less educated individuals are more likely to be employed in manual labor, which is linked to consumption of more fatty and calorie-dense food (e.g., meatheavy diets) to sustain poorly educated manual workers throughout the day [30]. Future studies are needed to test these and other potential mechanisms in Slovenia.

On the other hand, better educated Slovenians typically consumed milk and dairy more frequently in 2008 [19], which is inconsistent with our 2019 data analysis. The 
inconsistent results may be due to milk and dairy being heavily promoted in recent years not only in Slovenian popular media [59-61] but also by pharmacies [62], public health experts, and healthcare professionals as "nutritious" and "healthy" [63], and as especially good for bone health $[19,64,65]$. These public health recommendations run counter to overwhelming evidence in recent years suggesting that higher dairy intake is either unrelated to bone health or linked to worse bone health [66-69], in addition to being linked to worse general health and mortality outcomes [70,71].

Inconsistent with the 2008 study, where researchers found that fish consumption was most frequent among the better-educated [19], fish consumption showed no educational gradient in our study. A factor that may explain the differences might be our control of confounding factors, while the 2008 study examined only bivariate associations. These inconsistencies in results between the two studies indicate the need to consider confounding factors when examining the impact of education and other indicators of sustainable dietary patterns.

Currently being in the educational process also has an independent impact on sustainable practices. However, we found it linked only to lower meat consumption but not to the other three sustainability outcomes. Other studies similarly suggest that more sustainable diets (e.g., meat-reduced and meat-free diets) are more common among students than those currently not being in education, even after controlling for education [34].

We also found that sustainable attitudes are less prevalent among those with only primary education, while those with secondary or higher education have similarly prevalent sustainable attitudes. Our results are consistent with earlier studies, which overwhelmingly suggest that higher educational levels are linked to sustainable attitudes, including pro-environmental and degrowth attitudes [72,73].

Overall, much evidence suggests that education plays an important role in sustainable dietary practices in Western cultures; those who have more education report more sustainable dietary patterns. In fact, general educational level and education specific to particular sustainability areas (e.g., nutrition education) may be among the most important determinants of sustainable lifestyles. Low educational attainment, for example, is one of the barriers to adopting a more sustainable, plant-based diet [74]. It has previously also been argued that lack of nutrition education may be among the reasons that significant sections of the European population have been documented as being deficient in key food micronutrients [75]. However, our findings show that in Slovenia, an east-central European country, educational levels and current educational status independently impact two dietary patterns: they promote lower meat consumption and more sustainable attitudes.

Our study has several practical implications, especially those related to educational systems. The first measure may be introduced at the level of the study programs and the inclusion of sustainability content in various subjects. Since Slovenians with primary education report the least sustainable behavior and attitudes, curricula in primary schools should be given special attention. The second measure relates to teacher education. Teachers' knowledge of and attitudes towards sustainability should be examined during their undergraduate education and then across the teacher's entire professional development process concerning their conceptions of sustainable development and healthy lifestyle. Perceptions influence classroom behavior; if a teacher has positive perceptions and beliefs about a specific topic, s/he is more likely to expand on that topic and discuss it with his or her students. In addition, online self-education tools [76] might also prove effective in promoting sustainability.

One potential solution to increasing the role of education in promoting sustainable dietary patterns may lie in innovative pedagogical approaches. Several studies suggest that classic courses which merely include content on sustainability in standard university courses, e.g., economics, might not improve students' understanding and apprehension of sustainability and environmental issues [77]. There is evidence that problem-based learning and cooperative learning might effectively produce behavioral changes towards sustainability issues [78]. Since our results indicate attitudes low in sustainability across 
the Slovenian population, sustainability topics should be taught across various educational levels. A strong focus should particularly be in primary school education. However, health and information campaigns may be a double-edged sword. On the one hand, they might improve public health; on the other hand, they could simultaneously increase socioeconomic inequalities in health outcomes [79]. Public health campaigns favor people with more resources, including better educated people, because "they appeal to individual knowledge, behaviour and motivation" [28]. For this reason, focusing on groups with lower levels of education in health and sustainability campaigns is of paramount importance.

Our study has several limitations that need mentioning. First, causality cannot be inferred from cross-sectional data, and results may not generalize to non-Slovenian populations, owing to cross-cultural and cross-national differences in values, attitudes, and behaviors [80-82], including those concerning food and diet [83]. However, an important strength of our study is that we employed nationally representative survey data, so our findings can be generalized to the Slovenian adult population. Second, panel data tracking individuals, their educational careers, and their dietary behavior and attitudes would provide a more nuanced understanding of the role of education. Third, only a limited number of control variables were included in our multivariate models. Therefore, future studies should include other potential confounders, including parental socioeconomic status, personal values, political orientation, religiosity, and media use [84]. Fourth, we examined only a few indicators of sustainable behaviors and attitudes. Therefore, researchers should also focus on other aspects of sustainable practices, including the use of sustainable transportation, bicycle use, recycling behaviors, electricity and fuel conservation. Fifth, evidence suggests that the role of education may differ with regard to consumption of different types of food within food groups [85], indicating the need for researchers to differentiate between various types of foods, not only between food groups. Finally, future studies should examine the extent to which dietary patterns may explain some of the social inequalities in health among Slovenians that were detected in earlier studies [63].

\section{Conclusions}

Our study shows that a predominant proportion of Slovenians report low-sustainable dietary practices and hold low-sustainable attitudes with regard to health, environment, animals, and dietary minorities. Our findings indicate that educational level and current educational status impact the frequency of meat consumption and sustainable attitudes, suggesting that education does have an "enlightenment effect" on some aspects of sustainable dietary outcomes, but not on fish and milk consumption. Since our results show an educational gradient in meat-related behavior and attitudinal dietary patterns, public health and environmental campaigns should focus on the less-educated groups, encouraging their meat intake reduction and fostering more sustainable attitudes. Owing to the low-sustainable practices and attitudes across the general Slovenian population and the lack of educational impact on several examined indicators of sustainability, our study also highlights the need for effective educational and informational strategies related to dietary practices across educational groups, stressing the importance of food choice not only for one's health but also for other aspects of sustainability, including the environmental impact of food and the concomitant ethical issues with regard to animal-sourced foods. 
Author Contributions: Conceptualization, A.K., M.L. and M.J.; methodology, A.K., M.L. and M.J.; formal analysis, A.K.; writing-original draft preparation, A.K.; writing-review and editing, A.K., M.L. and M.J.; project administration, A.K. and M.J.; funding acquisition, A.K. and M.J. All authors have read and agreed to the published version of the manuscript.

Funding: This research was partly funded by the Slovenian Research Agency (ARRS), Grant number P6-0372 (B). The research was also partly funded by Creative Path to Knowledge (PKP, 2017-2020), financed by the Slovenian Ministry of Education, Science, and Sport and the European Union through the European Social Fund.

Institutional Review Board Statement: This study was exempt from review as it only uses anonymized, publicly available survey data.

Informed Consent Statement: Informed consent was obtained from all subjects involved in the study.

Data Availability Statement: The data presented in this study are available at https:/ /www.adp.fdv. uni-lj.si/opisi/sjm191/ (accessed on 23 September 2021).

Conflicts of Interest: The authors declare no conflict of interest. The funders had no role in the design of the study; in the collection, analyses, or interpretation of data; in the writing of the manuscript, or in the decision to publish the results.

\section{References}

1. Ruini, L.F.; Ciati, R.; Pratesi, C.A.; Marino, M.; Principato, L.; Vannuzzi, E. Working toward Healthy and Sustainable Diets: The "Double Pyramid Model" Developed by the Barilla Center for Food and Nutrition to Raise Awareness about the Environmental and Nutritional Impact of Foods. Front. Nutr. 2015, 2, 9. [CrossRef] [PubMed]

2. Tilman, D.; Clark, M. Global diets link environmental sustainability and human health. Nature 2014, 515, 518-522. [CrossRef]

3. Willett, W.; Rockström, J.; Loken, B.; Springmann, M.; Lang, T.; Vermeulen, S.; Garnett, T.; Tilman, D.; DeClerck, F.; Wood, A.; et al. Food in the Anthropocene: The EAT-Lancet Commission on healthy diets from sustainable food systems. Lancet 2019, 393, 447-492. [CrossRef]

4. Machovina, B.; Feeley, K.J.; Ripple, W.J. Biodiversity conservation: The key is reducing meat consumption. Sci. Total Environ. 2015, 536, 419-431. [CrossRef]

5. Segovia-Siapco, G.; Sabaté, J. Correction: Health and sustainability outcomes of vegetarian dietary patterns: A revisit of the EPIC-Oxford and the Adventist Health Study-2 cohorts. Eur. J. Clin. Nutr. 2019, 73, 968. [CrossRef]

6. Fiksel, J.R.; Tarsha, E.; Herbert, F. A Framework for Sustainability Indicators at EPA; US Environmental Protection Agency: Washington, DC, USA, 2012.

7. Kjærgård, B.; Land, B.; Bransholm Pedersen, K. Health and sustainability. Health Promot. Int. 2014, 29, 558-568. [CrossRef] [PubMed]

8. Burlingame, B.; Sandro, D. Sustainable Diets and Biodiversity: Directions and Solutions for Policy, Research and Action; FAO Headquarters: Rome, Italy, 2012.

9. Črnič, A. Studying social aspects of vegetarianism: A research proposal on the basis of a survey among adult population of two Slovenian biggest cities. Coll. Antropol. 2013, 37, 1111-1120.

10. Rothgerber, H. Horizontal hostility among non-meat eaters. PLoS ONE 2014, 9, e96457. [CrossRef]

11. Ruby, M.B. Vegetarianism; A blossoming field of study. Appetite 2012, 8, 141-150. [CrossRef]

12. Chai, B.C.; van der Voort, J.R.; Grofelnik, K.; Eliasdottir, H.G.; Klöss, I.; Perez-Cueto, F.J.A. Which Diet Has the Least Environmental Impact on Our Planet? A Systematic Review of Vegan, Vegetarian and Omnivorous Diets. Sustainability 2019, 11, 4110. [CrossRef]

13. Rohrmann, S.; Overvad, K.; Bueno-de-Mesquita, H.; Jakobsen, M.U.; Egeberg, R.; Tjønneland, A.; Nailler, L.; Boutron-Ruault, M.C.; Clavel-Chapelon, F.; Krogh, V.; et al. Meat consumption and mortality-results from the European Prospective Investigation into Cancer and Nutrition. BMC Med. 2013, 11, 63. [CrossRef]

14. WHO. Cancer: Carcinogenicity of the Consumption of Red Meat and Processed Meat. Available online: https://www. who.int/news-room/q-a-detail/cancer-carcinogenicity-of-the-consumption-of-red-meat-and-processed-meat (accessed on 29 August 2021).

15. Singer, P. Animal Liberation, 2nd ed.; Ecco: New York, NY, USA, 2002; ISBN 0060011572.

16. Foer, J.S. Eating Animals; Back Bay Books/Little Brown and Co.: New York, NY, USA, 2010; ISBN 9780316069885.

17. Lucas, T.; Horton, R. The 21st-century great food transformation. Lancet 2019, 393, 386-387. [CrossRef]

18. Singer, P. Why Vegan? Eating Ethically; Liveright Publishing Corporation: New York, NY, USA, 2020 ; ISBN 9780241472385.

19. Gabrijelčič Blenkuš, M.; Gregorič, M.; Tivadar, B.; Koch, V.; Kostanjevec, S.; Fajdiga Turk, V.; Žalar, A.; Lavtar, D.; Kuhar, D.; Rozman, U. Prehrambene Navade Odraslih Prebivalcev Slovenije z Vidika Varovanja Zdravja; Gabrijelčič Blenkuš, M., Gregorič, M., Tivadar, B., Koch, V., Kostanjevec, S., Fajdiga Turk, V., Žalar, A., Lavtar, D., Kuhar, D., Rozman, U., Eds.; Inštitut za Varovanje Zdravja Republike Slovenije: Ljubljana, Slovenia, 2009.

20. Gossard, M.H.; York, R. Social Structural Influences on Meat Consumption. Hum. Ecol. Rev. 2003, 10, 1-9. 
21. Koch, F.; Heuer, T.; Krems, C.; Claupein, E. Meat consumers and non-meat consumers in Germany: A characterisation based on results of the German National Nutrition Survey II. J. Nutr. Sci. 2019, 8, e21. [CrossRef] [PubMed]

22. Mackenbach, J.D.; Brage, S.; Forouhi, N.G.; Griffin, S.J.; Wareham, N.J.; Monsivais, P. Does the importance of dietary costs for fruit and vegetable intake vary by socioeconomic position? Br. J. Nutr. 2015, 114, 1464-1470. [CrossRef]

23. Benedetti, I.; Biggeri, L.; Laureti, T.; Secondi, L. Exploring the Italians' Food Habits and Tendency towards a Sustainable Diet: The Mediterranean Eating Pattern. Agric. Agric. Sci. Procedia 2016, 8, 433-440. [CrossRef]

24. Lacour, C.; Seconda, L.; Allès, B.; Hercberg, S.; Langevin, B.; Pointereau, P.; Lairon, D.; Baudry, J.; Kesse-Guyot, E. Environmental Impacts of Plant-Based Diets: How Does Organic Food Consumption Contribute to Environmental Sustainability? Front. Nutr. 2018, 5, 8. [CrossRef] [PubMed]

25. Krokstad, S.; Ding, D.; Grunseit, A.C.; Sund, E.R.; Holmen, T.L.; Rangul, V.; Bauman, A. Multiple lifestyle behaviours and mortality, findings from a large population-based Norwegian cohort study-The HUNT Study. BMC Public Health 2017, 17, 58. [CrossRef] [PubMed]

26. Aston, L.M.; Smith, J.N.; Powles, J.W. Meat intake in Britain in relation to other dietary components and to demographic and risk factor variables: Analyses based on the National Diet and Nutrition Survey of 2000/2001. J. Hum. Nutr. Diet. Off. J. Br. Diet. Assoc. 2013, 26, 96-106. [CrossRef] [PubMed]

27. Azizi Fard, N.; de Francisci Morales, G.; Mejova, Y.; Schifanella, R. On the interplay between educational attainment and nutrition: A spatially-aware perspective. EPJ Data Sci. 2021, 10, 10. [CrossRef]

28. Laursen, U.B.; Johansen, M.B.; Joensen, A.M.; Lau, C.J.; Overvad, K.; Larsen, M.L. Educational level and living arrangements are associated with dietary intake of red meat and fruit/vegetables: A Danish cross-sectional study. Scand. J. Public Health 2019, 47, 557-564. [CrossRef]

29. Einhorn, L. Meat consumption, classed? Osterr. Z. für Soziologie 2021, 46, 125-146. [CrossRef]

30. Vandermoere, F.; Geerts, R.; de Backer, C.; Erreygers, S.; van Doorslaer, E. Meat Consumption and Vegaphobia: An Exploration of the Characteristics of Meat Eaters, Vegaphobes, and Their Social Environment. Sustainability 2019, 11, 3936. [CrossRef]

31. Bryant, C.J. We Can't Keep Meating Like This: Attitudes towards Vegetarian and Vegan Diets in the United Kingdom. Sustainability 2019, 11, 6844. [CrossRef]

32. Gilsing, A.M.J.; Weijenberg, M.P.; Goldbohm, R.A.; Dagnelie, P.C.; van den Brandt, P.A.; Schouten, L.J. The Netherlands Cohort Study-Meat Investigation Cohort; a population-based cohort over-represented with vegetarians, pescetarians and low meat consumers. Nutr. J. 2013, 12, 156. [CrossRef]

33. Hoek, A.C.; Luning, P.A.; Stafleu, A.; de Graaf, C. Food-related lifestyle and health attitudes of Dutch vegetarians, non-vegetarian consumers of meat substitutes, and meat consumers. Appetite 2004, 42, 265-272. [CrossRef] [PubMed]

34. Einhorn, L. Food, Classed? Social Inequality and Diet: Understanding Stratified Meat Consumption Patterns in Germany. Available online: https:/ / kups.ub.uni-koeln.de/29386/1/Dissertation_Laura_Einhorn.pdf (accessed on 23 September 2021).

35. Barbosa, L.B.; Vasconcelos, S.M.L.; Correia, L.O.d.S.; Ferreira, R.C. Nutrition knowledge assessment studies in adults: A systematic review. Cienc. Saude Coletiva 2016, 21, 449-462. [CrossRef] [PubMed]

36. Obayashi, S.; Bianchi, L.J.; Song, W.O. Reliability and Validity of Nutrition Knowledge, Social-Psychological Factors, and Food Label Use Scales from the 1995 Diet and Health Knowledge Survey. J. Nutr. Educ. Behav. 2003, 35, 83-92. [CrossRef]

37. Petrovici, D.A.; Ritson, C. Factors influencing consumer dietary health preventative behaviours. BMC Public Health $2006,6,222$. [CrossRef]

38. Sun, Y.; Dong, D.; Ding, Y. The Impact of Dietary Knowledge on Health: Evidence from the China Health and Nutrition Survey. Int. J. Environ. Res. Public Health 2021, 18, 3736. [CrossRef] [PubMed]

39. Lea, E.J.; Crawford, D.; Worsley, A. Public views of the benefits and barriers to the consumption of a plant-based diet. Eur. J. Clin. Nutr. 2006, 60, 828-837. [CrossRef] [PubMed]

40. Dinu, M.; Abbate, R.; Gensini, G.F.; Casini, A.; Sofi, F. Vegetarian, vegan diets and multiple health outcomes: A systematic review with meta-analysis of observational studies. Crit. Rev. Food Sci. Nutr. 2017, 57, 3640-3649. [CrossRef]

41. Kim, H.; Caulfield, L.E.; Garcia-Larsen, V.; Steffen, L.M.; Coresh, J.; Rebholz, C.M. Plant-Based Diets Are Associated With a Lower Risk of Incident Cardiovascular Disease, Cardiovascular Disease Mortality, and All-Cause Mortality in a General Population of Middle-Aged Adults. J. Am. Heart Assoc. 2019, 8, e012865. [CrossRef]

42. Miles, F.L.; Lloren, J.I.C.; Haddad, E.; Jaceldo-Siegl, K.; Knutsen, S.; Sabate, J.; Fraser, G.E. Plasma, Urine, and Adipose Tissue Biomarkers of Dietary Intake Differ Between Vegetarian and Non-Vegetarian Diet Groups in the Adventist Health Study-2. J. Nutr. 2019, 149, 667-675. [CrossRef]

43. Orlich, M.J.; Fraser, G.E. Vegetarian diets in the Adventist Health Study 2: A review of initial published findings. Am. J. Clin. Nutr. 2014, 100, 353S-358S. [CrossRef] [PubMed]

44. Tantamango-Bartley, Y.; Jaceldo-Siegl, K.; Fan, J.; Fraser, G. Vegetarian diets and the incidence of cancer in a low-risk population. Cancer Epidemiol. Biomarkers Prev. 2013, 22, 286-294. [CrossRef]

45. Graça, J.; Calheiros, M.M.; Oliveira, A. Attached to meat? (Un)Willingness and intentions to adopt a more plant-based diet. Appetite 2015, 95, 113-125. [CrossRef] [PubMed]

46. Leiserowitz, A.A.; Kates, R.W.; Parris, T.M. Sustainability Values, Attitudes, and Behaviors: A Review of Multinational and Global Trends. Annu. Rev. Environ. Resour. 2006, 31, 413-444. [CrossRef] 
47. Dražanová, L. Education and Tolerance: A Comparative Quantitative Analysis of the Educational Effect on Tolerance; Peter Lang Edition: Frankfurt am Main, Germany, 2017; ISBN 9783631718643.

48. Kirbiš, A.; Flere, S.; Tavčar Krajnc, M. Netolerantnost v Sloveniji in Evropi: Primerjalna in longitudinalna analiza. Druž. Razpr. 2012, 28, 27-50.

49. Valli, C.; Rabassa, M.; Johnston, B.C.; Kuijpers, R.; Prokop-Dorner, A.; Zajac, J.; Storman, D.; Storman, M.; Bala, M.M.; Solà, I.; et al. Health-Related Values and Preferences Regarding Meat Consumption: A Mixed-Methods Systematic Review. Ann. Intern. Med. 2019, 171, 742-755. [CrossRef]

50. Marquart-Pyatt, S.T. Environmental Concerns in Cross-National Context: How Do Mass Publics in Central and Eastern Europe Compare with Other Regions of the World? Czech Sociol. Rev. 2012, 48, 441-466. [CrossRef]

51. Hafner Fink, M.; Dolenc, E.; Slabe, D.; Kovačič, U.; Bevk, T.; Golobič, M. Slovensko Javno Mnenje 2019/1; Univerza v Ljubljani: Ljubljana, Slovenia, 2021.

52. ISSP. Organisational Structure and Working Principles. Available online: http:/ /w.issp.org/about-issp/organisation/ (accessed on 4 November 2021).

53. ISSP. International Social Survey Programme; Ethical Statement; International Social Survey Programme: Lausanne, Switzerland, 2021.

54. ADP. Slovenian Public Opinion 2019/1: Slovenian Public Opinion 2019/1: Mirror of Public Opinion, ISSP Religion IV, Use of Renewable Energy Sources, Vegetarianism and Veganism, Attitude towards First Aid, Use of the Internet and Social Networks, Hate Speech (Study Description). Available online: https://www.adp.fdv.uni-lj.si/opisi/sjm191/ (accessed on 22 September 2021).

55. Zhong, V.W.; van Horn, L.; Greenland, P.; Carnethon, M.R.; Ning, H.; Wilkins, J.T.; Lloyd-Jones, D.M.; Allen, N.B. Associations of Processed Meat, Unprocessed Red Meat, Poultry, or Fish Intake With Incident Cardiovascular Disease and All-Cause Mortality. JAMA Intern. Med. 2020, 180, 503-512. [CrossRef] [PubMed]

56. An, R.; Nickols-Richardson, S.M.; Alston, R.J.; Shen, S.; Clarke, C. Fresh- and lean-pork intake in relation to functional limitations among US older adults, 2005-2016. Nutr. Health 2020, 26, 295-301. [CrossRef]

57. Raghupathi, V.; Raghupathi, W. The influence of education on health: An empirical assessment of OECD countries for the period 1995-2015. Arch. Public Health 2020, 78, 20. [CrossRef] [PubMed]

58. Weerasekara, P.C.; Withanachchi, C.R.; Ginigaddara, G.A.S.; Ploeger, A. Food and Nutrition-Related Knowledge, Attitudes, and Practices among Reproductive-Age Women in Marginalized Areas in Sri Lanka. Int. J. Environ. Res. Public Health 2020, 17, 3985. [CrossRef] [PubMed]

59. 24UR. Miti in Dejstva o Mlečnih Izdelkih: Jogurt, Kefir, Kislo Mleko med Najbolj Zdravimi. 19 August 2017. Available online: https://www.24ur.com/specialno/nega_in_zdravje/najbolj-zdravi-so-fermentirani-mlecni-izdelki.html (accessed on 21 September 2021).

60. RTVSLO. Slovenski Raziskovalci Dokazali, da Kravje Mleko ni Zdravju Škodljivo. Available online: https://www.rtvslo.si/ znanost-in-tehnologija/slovenski-raziskovalci-dokazali-da-kravje-mleko-ni-zdravju-skodljivo/399657 (accessed on 21 September 2021).

61. STA. Mlečna Maščoba ne Maši Žil, Deluje Lahko Celo Preventivno. 6 September 2018. Available online: https://www.24ur.com/ fit-24ur/mlecna-mascoba-ne-masi-zil-deluje-lahko-celo-preventivno.html (accessed on 21 September 2021).

62. Merljak, M. Zakaj je Mleko Zdravo? Available online: https://www.nasa-lekarna.si/clanki/clanek/zakaj-je-mleko-zdravo/ (accessed on 21 September 2021).

63. Lesnik, T.; Gabrijelčič Blenkuš, M.; Hočevar Grom, A.; Kofol Bric, T.; Zaletel, M. Neenakosti v Zdravju v Sloveniji v Času Ekonomske Krize; Lesnik, T., Gabrijelčič Blenkuš, M., Hočevar Grom, A., Kofol Bric, T., Zaletel, M., Eds.; Nacionalni inštitut za javno zdravje: Ljubljana, Slovenia, 2018.

64. NIJZ. Mleko in Mlekomati. Available online: https://www.nijz.si/sl/mleko-in-mlekomati (accessed on 21 September 2021).

65. NIJZ. Izvajanje Šolske Sheme v Sloveniji-Mleko in Mlečni Izdelki. Available online: https://www.nijz.si/sl/izvajanje-solskesheme-v-sloveniji-mleko-in-mlecni-izdelki (accessed on 21 September 2021).

66. Bian, S.; Hu, J.; Zhang, K.; Wang, Y.; Yu, M.; Ma, J. Dairy product consumption and risk of hip fracture: A systematic review and meta-analysis. BMC Public Health 2018, 18, 165. [CrossRef] [PubMed]

67. Bischoff-Ferrari, H.A.; Dawson-Hughes, B.; Baron, J.A.; Kanis, J.A.; Orav, E.J.; Staehelin, H.B.; Kiel, D.P.; Burckhardt, P.; Henschkowski, J.; Spiegelman, D.; et al. Milk intake and risk of hip fracture in men and women: A meta-analysis of prospective cohort studies. J. Bone Miner. Res. 2011, 26, 833-839. [CrossRef]

68. Feskanich, D.; Bischoff-Ferrari, H.A.; Frazier, A.L.; Willett, W.C. Milk consumption during teenage years and risk of hip fractures in older adults. JAMA Pediatrics 2014, 168, 54-60. [CrossRef]

69. Michaëlsson, K.; Wolk, A.; Langenskiöld, S.; Basu, S.; Warensjö Lemming, E.; Melhus, H.; Byberg, L. Milk intake and risk of mortality and fractures in women and men: Cohort studies. BMJ 2014, 349, g6015. [CrossRef]

70. Ding, M.; Li, J.; Qi, L.; Ellervik, C.; Zhang, X.; Manson, J.E.; Stampfer, M.; Chavarro, J.E.; Rexrode, K.M.; Kraft, P.; et al. Associations of dairy intake with risk of mortality in women and men: Three prospective cohort studies. BMJ 2019, 367, 16204. [CrossRef]

71. Wang, X.J.; Jiang, C.Q.; Zhang, W.S.; Zhu, F.; Jin, Y.L.; Woo, J.; Cheng, K.K.; Lam, T.H.; Xu, L. Milk consumption and risk of mortality from all-cause, cardiovascular disease and cancer in older people. Clin. Nutr. 2020, 39, 3442-3451. [CrossRef] [PubMed]

72. Ančić, B.; Domazet, M. Potential for degrowth: Attitudes and behaviours across 18 European countries. Teor. Praksa 2015, 52, 456-475. 
73. Quaglione, D.; Cassetta, E.; Crociata, A.; Sarra, A. Exploring additional determinants of energy-saving behaviour: The influence of individuals' participation in cultural activities. Energy Policy 2017, 108, 503-511. [CrossRef]

74. Pohjolainen, P.; Vinnari, M.; Jokinen, P. Consumers' perceived barriers to following a plant-based diet. Br. Food J. 2015, 117, 1150-1167. [CrossRef]

75. Biesalski, H.K. Sustainable Micronutrients in Europe: Is There Cause for Concern? In Sustainable Nutrition in a Changing World; Biesalski, H.K., Ed.; Springer: Cham, Switzerland, 2017; pp. 143-166, ISBN 9783319559421.

76. Fedushko, S.; Syerov, Y.; Tesak, O.; Onyshchuk, O.; Melnykova, N. Advisory and accounting tool for safe and economically optimal choice of online self-education services. CEUR Workshop Proc. 2019, 2588, 290-300.

77. Green, T.L. Teaching (un)sustainability? University sustainability commitments and student experiences of introductory economics. Ecol. Econ. 2013, 94, 135-142. [CrossRef]

78. Aziz, A.A.; Yusof, K.M.; Udin, A.; Yatim, J.M. Development of Students' Knowledge-behavioural Changes in Relation to Sustainability through a Case Study. Procedia-Soc. Behav. Sci. 2013, 102, 568-576. [CrossRef]

79. Adler, N.E.; Newman, K. Socioeconomic disparities in health: Pathways and policies. Health Aff. 2002, 21, 60-76. [CrossRef]

80. Inglehart, R.; Welzel, C. Modernization, Cultural Change, and Democracy: The Human Development Sequence/Ronald Inglehart, Christian Welzel; Cambridge University Press: Cambridge, UK, 2005; ISBN 0521609712.

81. Schwartz, S.H. Are There Universal Aspects in the Structure and Contents of Human Values? J. Soc. Issues 1994, 50, 19-45. [CrossRef]

82. Schwartz, S.H.; Cieciuch, J.; Vecchione, M.; Davidov, E.; Fischer, R.; Beierlein, C.; Ramos, A.; Verkasalo, M.; Lönnqvist, J.-E.; Demirutku, K.; et al. Refining the theory of basic individual values. J. Pers. Soc. Psychol. 2012, 103, 663-688. [CrossRef]

83. Rozin, P. The Meaning of Food in Our Lives: A Cross-Cultural Perspective on Eating and Well-Being. J. Nutr. Educ. Behav. 2005, 37, S107-S112. [CrossRef]

84. Zafar, A.U.; Shen, J.; Ashfaq, M.; Shahzad, M. Social media and sustainable purchasing attitude: Role of trust in social media and environmental effectiveness. J. Retail. Consum. Serv. 2021, 63, 102751. [CrossRef]

85. Pfeiler, T.M.; Egloff, B. Personality and meat consumption: The importance of differentiating between type of meat. Appetite 2018, 130, 11-19. [CrossRef] [PubMed] 